Brit. Heart f., 1969, 31, 636.

\title{
Plasma and Myocardial Digoxin Concentrations in Patients on Oral Therapy
}

\author{
P. F. BINNION, L. M. MORGAN, H. M. STEVENSON, AND E. FLETCHER \\ From the Cardiovascular Unit, Belfast City Hospital, and Foster Green Hospital, Belfast
}

Methods are now available which are sensitive enough to detect digoxin concentration to levels of $5 \mathrm{~m} \mu \mathrm{g} . / \mathrm{ml}$. Hitherto the degree of sensitivity of specific chemical methods was not acceptable for clinical application. Digoxin-specific antibodies have recently been prepared (Butler and Chen, 1967), and a test based on the radioimmunoassay principle has now been used to measure plasma digoxin levels (Oliver et al., 1968). The double isotope dilution technique is a specific and very sensitive method for measuring steroids in biological extracts, and it has been applied successfully to determining plasma digitoxin levels in man (Lukas and Peterson, 1966). However, there are no reports on its use for measuring plasma digoxin.

The methods using the isotope dilution or radioimmunoassay techniques are technically difficult and laborious, but Lowenstein has used a biological assay technique based on the inhibition of the uptake of ${ }^{86}$ rubidium by human red cells in the presence of small quantities of glycosides (Lowenstein, 1965; Lowenstein and Corrill, 1966; Morgan and Binnion, 1967). Multiple plasma samples containing no acetyl strophanthidin gave a result above $2 \mathrm{~m} \mu \mathrm{g} . / \mathrm{ml}$. in 1 in every 7 samples (P. F. Binnion, S. A. Hawkins, and L. M. Morgan, 1969, Acetyl strophanthidin tolerance test. The relationship between plasma levels of acetyl strophanthidin and potassium and induced dysrhythmias. Unpublished observations), but the method is relatively easy to perform and is as sensitive as more elaborate methods.

The results of plasma digoxin concentrations in patients on oral therapy and also the myocardial concentrations of the glycoside determined in other patients undergoing mitral valvotomy are presented. In this way it is possible to see whether plasma levels reflect myocardial concentrations, for it must be the concentration of the digitalis glycoside in the

Received March 27, 1969. cardiac tissue (together with the response of the tissue) which ultimately determines the effect of the drug.

\section{Patients and Methods}

Plasma Samples. Venous blood was obtained from 10 digitalized patients one hour after $0.25 \mathrm{mg}$. digoxin had been administered orally. None had any evidence of digitalis toxicity. In all, 23 blood samples were obtained on separate days, and after centrifugation, the plasma was removed and stored at below $4^{\circ} \mathrm{C}$. until the assay was performed.

Atrial Samples. A piece of left atrial appendage was obtained from 16 patients ( 4 men, 12 women) who were undergoing closed mitral valvotomy for mitral stenosis. Before the operation these patients were considered adequately digitalized on clinical criteria. Details of their digitalis dosage and other therapy are given (see Table II), and from the nursing notes, both pre- and post-operative, the maximum recorded pulse rates have been abstracted in an attempt to determine whether any patient could be considered to have had inadequate digitalis dosage (the maximum post-operative pulse rate was that determined within 24 hours of the operation). No patient had any oral digoxin for 24 hours before operation.

Plasma Digoxin Determination. Two $\mathrm{ml}$. dichloromethane were added to $1 \mathrm{ml}$. plasma and the mixture was shaken vigorously for 5 minutes and left overnight at $5^{\circ} \mathrm{C}$. The mixture was centrifuged for 10 minutes at $1500 \mathrm{~g}$ the following morning and the aqueous supernatant and lipid debris were removed by suction. One $\mathrm{ml}$. of the clear dichloromethane extract was transferred to a round-bottomed glass-tube and evaporated to dryness in a water bath at $25^{\circ} \mathrm{C}$. overnight. One $\mathrm{ml}$. solution of saline containing $100 \mathrm{mg}$. per $100 \mathrm{ml}$. glucose and $5 \mathrm{mg}$. per $100 \mathrm{ml}$. adenine sulphate (freshly prepared) was added to the dry dichloromethane extract. $2.5 \mu \mathrm{Ci}{ }^{86}$ rubidium chloride (Radiochemical Centre, Amersham) was added, and the tube placed in a shaking water bath at $38^{\circ} \mathrm{C}$. for 10 minutes. 
Freshly drawn group $\mathbf{O} \mathbf{R h}$ positive blood (using EDTA as anticoagulant) was washed twice with icecold saline and the red cells suspended in a small volume of ice-cold saline. One $\mathrm{ml}$. of this suspension was then added to the dichloromethane extract mixture and returned to the shaking incubator for a further 2 hours at $38^{\circ} \mathrm{C}$. During this incubation the tubes were counted in a well-type scintillation counter (pre-incubation count). At the end of this incubation period, the tubes were removed from the incubator and plunged in ice and the red cells were washed three times with ice-cold saline (by alternate suspension and centrifugation) and counted in the packed state (post-incubation count).

The ratio of post-incubation to pre-incubation count is referred to as the ${ }^{86} \mathrm{Rb}$ uptake index, i.e.:

${ }^{86} \mathrm{Rb}$ uptake index $=\frac{\text { Post-incubation counts }}{\text { Pre-incubation counts }} \times 100$

Per cent ${ }^{86} \mathrm{Rb}$ uptake inhibition $=100-{ }^{86} \mathrm{Rb}$ uptake index.

Atrial Digoxin Determination. Atrial appendages from the above patients were kept at $-20^{\circ} \mathrm{C}$., and a known weight was homogenized in a Waring blender in icecold saline. The total volume was made up to $5 \mathrm{ml}$., and $10 \mathrm{ml}$. dichloromethane were added, and the extraction was identical to the one used for the extraction of digoxin from plasma except that $2.5 \mathrm{ml}$. of the dichloromethane extract was used for analysis.

Digoxin Calibration Curves (Fig.). A pool of plasma was obtained to which was added a known quantity of purified digoxin (Burroughs Wellcome, London). Various dilutions were made of this stock solution with plasma to give a series of final concentrations ranging from $2 \cdot 5-500 \mathrm{~m} \mu \mathrm{g} . / \mathrm{ml}$. The extraction procedure was identical to the above and the tubes treated in the same way as mentioned. In the case of the atrial appendages a calibration curve was constructed as follows. An atrial appendage was obtained at necropsy from a patient who had not been on prior digitalis therapy, and this was homogenized, and a known amount of purified digoxin

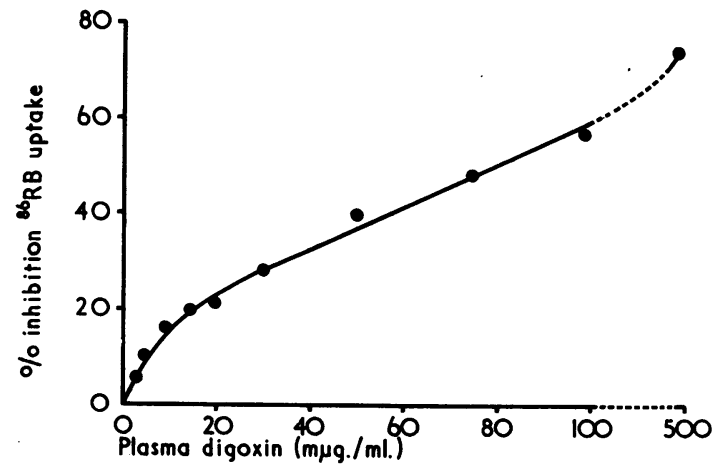

FIG.-Calibration curve for estimating the concentration of digoxin in plasma based on the inhibition of the uptake of ${ }^{86} \mathrm{Rb}$ by human red cells. was added to the homogenate. Solutions of this homogenate were then made to provide a range of concentrations extending from 2.5 to $500 \mathrm{~m} \mu \mathrm{g} . / \mathrm{g}$. atrial tissue. The standards were processed in exactly the same way as the unknowns.

Quality Control. Three plasma specimens from patients were obtained and $250 \mathrm{~m} \mu \mathrm{g} . / \mathrm{ml}$. digoxin added, and these were treated in exactly the same way as the unknown plasma samples. In addition, atrial appendages were obtained at necropsy from 2 patients who had not been on any digitalis therapy and these tissues were homogenized. Digoxin was added to the homogenate to give a concentration of 20 and $70 \mathrm{~m} \mu \mathrm{g} . / \mathrm{g}$. atrial tissue, and the extraction and method of determining digoxin concentration were identical to those used for atrial appendages obtained at operation.

\section{RESULTS}

Plasma Digoxin. The plasma digoxin levels are given in Table $I$, and they all lie within the range $0 \cdot 1-2.5 \mathrm{~m} \mu \mathrm{g} . / \mathrm{ml}$. plasma (mean $=0.6 \mathrm{~m} \mu \mathrm{g} . / \mathrm{ml}$, $\mathrm{SE}= \pm 0 \cdot 1)$. The variation between different individuals and between plasma samples taken on different days from the same individual is small.

TABLE I

PLASMA DIGOXIN LEVELS IN PATIENTS ON ORAL DIGOXIN THERAPY

\begin{tabular}{|c|c|c|}
\hline Case No. & $\begin{array}{l}\text { Age } \\
\text { (yr.) }\end{array}$ & $\begin{array}{l}\text { Plasma digoxin } \\
(\mathrm{m} \mu \mathrm{g} . / \mathrm{ml} .)\end{array}$ \\
\hline 1 & 46 & $\begin{array}{l}0.1 \\
1.0\end{array}$ \\
\hline 2 & 56 & $\begin{array}{l}2.5 \\
0.5\end{array}$ \\
\hline 3 & 73 & $\begin{array}{l}0.5 \\
0.5 \\
0.5\end{array}$ \\
\hline 4 & 59 & $\begin{array}{l}0.5 \\
0.5 \\
2.0\end{array}$ \\
\hline 5 & 51 & $\begin{array}{l}0.1 \\
0.3\end{array}$ \\
\hline 6 & - & $0 \cdot 1$ \\
\hline 7 & - & $\begin{array}{l}0.2 \\
0.1 \\
0.1 \\
0.8\end{array}$ \\
\hline 8 & 29 & $\begin{array}{l}0.4 \\
2.0 \\
0.1 \\
2.0\end{array}$ \\
\hline 9 & 57 & $\begin{array}{l}0.4 \\
0.3\end{array}$ \\
\hline 10 & 52 & $\begin{array}{l}0.1 \\
0.3 \\
0.4 \\
0.1\end{array}$ \\
\hline $\begin{array}{l}\text { Mean } \\
\text { Standard error }\end{array}$ & $=$ & $\begin{array}{r}0.6 \\
\pm 0.1\end{array}$ \\
\hline
\end{tabular}


TABLE II

CLINICAL DETAILS AND MYOCARDIAL (ATRIAL) DIGOXIN CONCENTRATION IN PATIENTS UNDERGOING CLOSED MITRAL VALVOTOMY

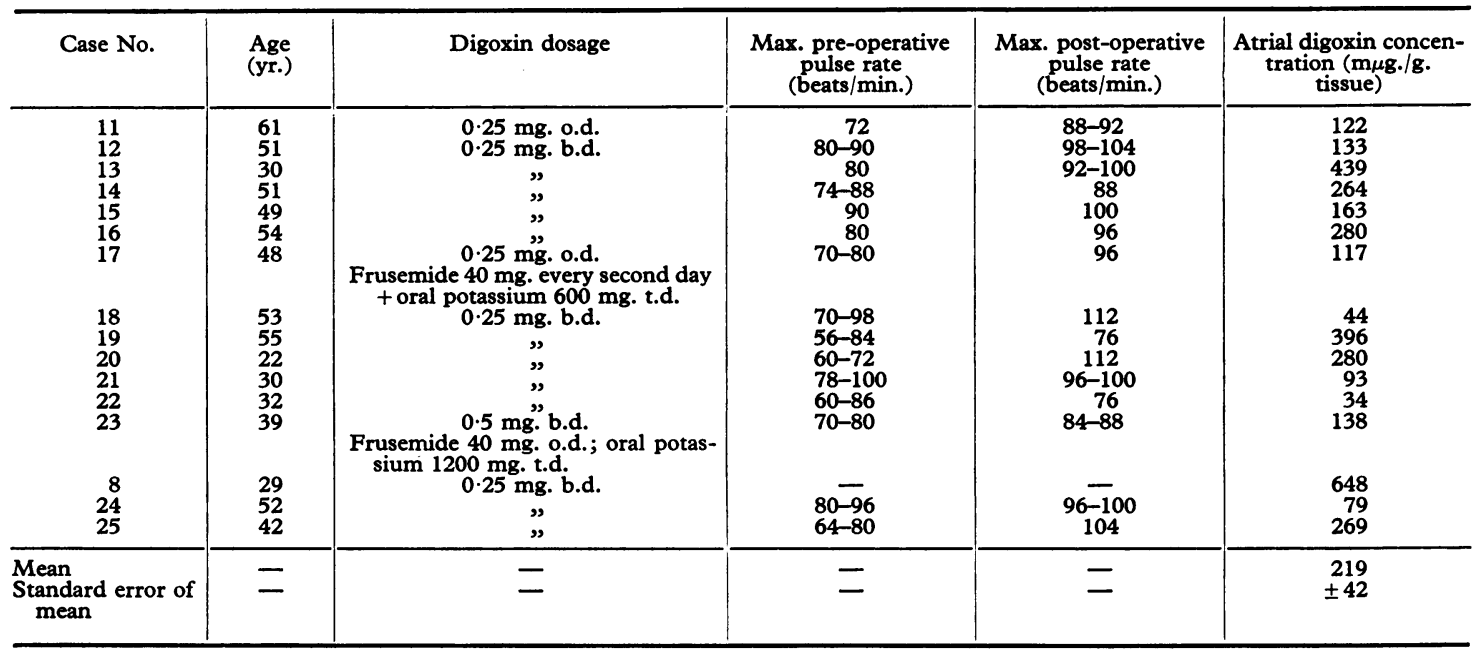

Atrial Digoxin Concentration (Table II). In the samples of atrial appendages obtained from patients at operation, the digoxin concentration varied from 34-648 m $\mu \mathrm{g}$./g. atrial tissue (mean $=219 \mathrm{~m} \mu \mathrm{g}$./g.; $\mathrm{SE}= \pm 42$ ), though 75 per cent of the values lay between 93 and $439 \mathrm{~m} \mu \mathrm{g} . / \mathrm{g}$. tissue. There was no evidence from the recorded pulse rates or any other information in the patients' records to indicate that patients with the lower atrial digoxin concentrations were less adequately digitalized than the other patients. One person (Case 21) was in normal sinus rhythm before the operation, changed to atrial fibrillation after the operation when her digoxin dosage was changed from $0.25 \mathrm{mg}$. daily to $0.25 \mathrm{mg}$. twice daily, and reverted to her original rhythm two days later. The wide range of atrial digoxin concentrations did not reflect the digitalis status of the patients as ascertained by clinical assessment.

Accuracy of Method. Table III shows how much of the added digoxin was measured by the procedures mentioned above. In the two normal atrial appendages to which 20 and $70 \mathrm{~m} \mu \mathrm{g}$. digoxin were added to each gram of atrial tissue, the digoxin values determined from the rubidium uptake curve

TABLE III

RECOVERY RATE FOR PLASMA DIGOXIN

\begin{tabular}{c|c|c}
\hline Plasma sample & $\begin{array}{c}\text { Digoxin added } \\
(\mathrm{m} \mu \mathrm{g} . / \mathrm{ml} .)\end{array}$ & $\begin{array}{c}\text { Digoxin estimation } \\
(\mathbf{m} \mu \mathrm{g} \cdot / \mathrm{ml} .)\end{array}$ \\
\hline 2 & 250 & 200 \\
6 & 250 & 260 \\
9 & 250 & 210 \\
\hline
\end{tabular}

were 20 and $70 \mathrm{~m} \mu \mathrm{g} . / \mathrm{g}$. The procedure was done without knowledge of the particular samples being estimated, and this value was only obtained from the red cell counts after the above calculations had been performed.

\section{Discussion}

The method used in this paper for plasma digoxin gave an average level of $0.6 \mathrm{~m} \mu \mathrm{g} . / \mathrm{ml}$. Plasma digoxin levels between 0 and $5 \mathrm{~m} \mu \mathrm{g} . / \mathrm{ml}$. have been found by other workers using the red cell method (Lowenstein and Corrill, 1966) and the less sensitive radioimmunoassay technique (Oliver et al., 1968). After completion of this study, the paper by Grahame-Smith and Everest (1969) was published, and they were able to determine accurately plasma levels of digoxin between 0 and $5 \mathrm{~m} \mu \mathrm{g} . / \mathrm{ml}$. by using $5 \mathrm{ml}$. plasma instead of the $1 \mathrm{ml}$. we employed. They found levels of $0.8-4.5 \mathrm{~m} \mu \mathrm{g} . / \mathrm{ml}$. plasma in patients who were on oral therapy and did not show signs of digitalis intoxication. Hence, in adequately digitalized patients the plasma digoxin level is usually below $5 \mathrm{~m} \mu \mathrm{g} . / \mathrm{ml}$. Adequate digitalization by digitoxin produces a higher level of plasma glycoside, of the order of five- to tenfold, compared with patients receiving oral digoxin. When a maintenance dose of digitoxin is used the plasma levels of patients not showing toxic effects are $10-50 \mathrm{~m} \mu \mathrm{g} . / \mathrm{ml}$. (Lowenstein and Corrill, 1966), 10-56 $\mathrm{m} \mu \mathrm{g} . / \mathrm{ml}$. (Lukas and Peterson, 1966), 4-60 $\mathrm{m} \mu \mathrm{g} . / \mathrm{ml}$. (Oliver et al., 1968), and 54-62 $\mathrm{m} \mu \mathrm{g} . / \mathrm{ml}$. (P. F. Binnion, A. M. Pollock, L. M. Morgan, and E. Fletcher, 1969, unpublished observations). 
In view of the above, it becomes more apparent that adequate digitalis therapy probably depends on the myocardial concentrations of the glycoside rather than on plasma levels, and others have expressed a similar view (Doherty and Perkins, 1966; Grahame-Smith and Everest, 1969). It appears that a relatively wide range of digoxin concentration in atrial tissue is commensurate with satisfactory digitalization. There was no significant evidence that the lowest atrial concentrations (below 100 $\mathrm{m} \mu \mathrm{g} . / \mathrm{g}$. atrial tissue) caused inadequate digitalization from a clinical standpoint. The average atrial concentration of digoxin was about one hundred times greater than plasma concentrations using this radiobioassay technique. There are no other estimates in earlier reports for results in patients on routine maintenance therapy, though work on glycosides labelled with isotope has been done comparing plasma and myocardial levels in acute experiments. Using ${ }^{3} \mathrm{H}$-ouabain in patients undergoing open heart repair of congenital septal defects, one group of workers noted that atrial tissue contained 5-10 times the plasma concentration 30-90 minutes after giving the glycoside intravenously (Marks et al., 1964), whereas when tritiated digoxin was given intravenously 6 hours before cardiopulmonary bypass, the ratio of myocardial to serum digoxin concentration in 10 patients was $67: 1$ (Beall et al., 1963). The maximum ratio between myocardial and serum digoxin concentration in dogs was 58:1 12 hours after a single injection of tritiated glycoside (Doherty and Perkins, 1966). Our results in patients are of a similar order of magnitude to the results of other workers mentioned above.

The wide variation in atrial digoxin concentrations mentioned in this paper is not unexpected in view of the poor relation between clinical therapy and patient size, condition, etc. As all the samples were taken 24 hours after the last dose of oral digoxin had been given, the glycoside must be fixed to cardiac tissue for some time. Doherty, Perkins, and Mitchell (1961) noted that one patient given oral ${ }^{3} \mathrm{H}$-digoxin 4 days before death had a significant amount in the heart at death, whereas one who died 8 months after an oral dose had no radioactivity in the heart tissue. Using dogs, Doherty and Perkins (1966) noted that the tissue half-life for tritiated digoxin in dog myocardium was 26 hours. However, none of these results is applicable to maintenance digoxin therapy as in the patients described above, and in fact it has been stated (Doherty and Perkins, 1966) that maintenance digoxin dosage studies are necessary to evaluate the usefulness of serum digoxin in estimating myocardial digoxin.
With reference to the wide variation in atrial content of digoxin in patients clinically digitalized, the work of Kuschinsky, Lüllmann, and Van Zwieten (1968) is pertinent. They have calculated that only about 0.006 per cent of the myocardial cell membrane needs to be covered by ouabain, and that most of the glycoside accumulated by their preparations was not of any importance for the pharmacological action of the drug. If one can extrapolate their work to ours on patients, it may be suggested that a wide variation in atrial digoxin content is still commensurate with full activity of the glycoside, for most of the accumulated digoxin is unnecessary for full activity and hence clinical digitalization. It is not possible for us to state how little glycoside in the heart is compatible with digitalization of the patient.

\section{SUMMARY}

Plasma and atrial digoxin concentrations were measured in patients who were adequately digitalized on clinical criteria. The method used was based on the inhibition of the uptake of ${ }^{86} \mathrm{Rb}$ by human red cells in the presence of small amounts of digoxin, and details regarding the accuracy of the method are given.

Plasma digoxin levels averaged $0.6 \mathrm{~m} \mu \mathrm{g} / \mathrm{ml}$. $(\mathrm{SE} \pm 0.1)$ and did not exceed $2.5 \mathrm{~m} \mu \mathrm{g} . / \mathrm{ml}$, while the amount in atrial tissue of patients undergoing closed mitral valvotomy averaged $219 \mathrm{~m} \mu \mathrm{g}$./g. atrial tissue $(S E \pm 42)$.

Digoxin appears to be fixed in significant amounts to atrial tissue 24 hours after the last oral dose, and there is no apparent relation between plasma and myocardial digoxin concentrations.

It appears that a wide range of concentrations of digoxin in myocardial tissue is consistent with clinical digitalization, possibly because most of the digoxin in the heart is not necessary for the full activity of the drug.

We wish to thank Dr. Patricia Morton for permission to study patients under her care.

\section{REFERENCES}

Beall, A. C., Johnson, P. C., Driscoll, T., Alexander, J. K., Dennis, E. W., McNamara, D. G., Cooley, D. A., and DeBakey, M. E. (1963). Effect of total cardiopulmonary bypass on myocardial and blood digoxin concentration in man. Amer. F. Cardiol., 11, 194.

Butler, V. P., and Chen, J. P. (1967). Digoxin-specific antibodies. Proc. nat. Acad. Sci. (Wash.), 57, 71.

Doherty, J. E., and Perkins, W. H. (1966). Tissue concentration and turnover of tritiated digoxin in dogs. Amer. F. Cardiol., 17, 47

, and Mitchell, G. K. (1961). Tritiated digoxin studies in human subjects. Arch. intern. Med., 108, 531. 
Grahame-Smith, D. G., and Everest, M. S. (1969). Measurement of digoxin in plasma and its use in diagnosis of digoxin intoxication. Brit. med. F., 1, 286.

Kuschinsky, K., Lüllmann, H., and Van Zwieten, P. A. (1968). A comparison of the accumulation and release of ${ }^{3} \mathrm{H}$ ouabain and ${ }^{3} \mathrm{H}$-digitoxin by guinea-pig heart muscle. Brit. F. Pharmacol., 32, 598.

Lowenstein, J. M. (1965). A method for measuring plasma levels of digitalis glycosides. Circulation, 31, 228.

—, and Corrill, E. M. (1966). An improved method for measuring plasma and tissue concentrations of digitalis glycosides. F. Lab. clin. Med., 67, 1048.

Lukas, D. S., and Peterson, R. E. (1966). Double isotope dilution derivative assay of digitoxin in plasma, urine, and stool of patients maintained on the drug. $\mathfrak{f}$. clin. Invest., 45, 782.

Marks, B. H., Dutta, S., Gauthier, J., and Elliott, D. (1964). Distribution in plasma, uptake by the heart and excretion of ouabain- $\mathrm{H}^{3}$ in human subjects. F. Pharmacol. exp. Ther., 145, 351.

Morgan, L. M., and Binnion, P. F. (1967). The estimation of digoxin in millimicrogram quantities using an erythrocyte-rubidium uptake technique. Irish f. med. Sci., 6th Ser., No. 503, p. 536.

Oliver, G. C., Parker, B. M., Brasfield, D. L., and Parker, C. W. (1968). The measurement of digitoxin in human serum by radioimmunoassay. $\mathcal{F}$. clin. Invest., 47, 1035. 